\title{
Aortic Dissection Manifested as Bilateral Leg Pain, Weakness and Paresthesia
}

\author{
Bilateral Bacak Ağrısı, Güçsüzlük ve Uyuşma ile Başvuran Aort Diseksiyonu
}

Serkan Emre Eroğlu, Sefer Özkaya, Özge Ecmel Onur, Arzu Denizbaşı, Çiğdem Özpolat, Hasan Demir, Haldun Akoğlu

Department of Emergency Medicine, Marmara University Faculty of Medicine, İstanbul, Turkey

\section{ABSTRACT}

Introduction: Aortic dissection is a challenging clinical emergency situation. Symptoms and signs can be produced by rupture or the occlusion of a major vessel. We present a case of aortic dissection that presented to the emergency department with neurovascular symptoms.

Case Report: A 55-year-old woman was admitted to our emergency department because of a sudden inability to walk and severe leg pain. She had known hypertension. Her distal pulses were weak, and the legs were cold and pale. She had motor deficits in the lower extremities, too. Her computed tomography revealed aortic dissection from the root of the aorta to the common iliac arteries.

Results: Presentation of aortic dissection with neurovascular manifestations is not so common. Despite significant advances in diagnostic and therapeutic techniques, morbidity and mortality rates remain high. So, a high clinical index of suspicion and early diagnosis are necessary.

Keywords: Aortic dissection, leg pain, neurovascular symptoms

Received: 13.02.2013 Accepted: 13.05.2013

\section{ÖZET}

Giriş: Aort diseksiyonu zor tanı konan klinik bir acil durumdur. Semptom ve bulgular ana damarın tıkanması ya da rüptürü ile oluşabilir. Biz bu vakada acil servise nörovaskular semptomlarla başvuran bir aort diseksiyon vakasını sunmaya çalıştık.

Olgu Sunumu: 55 yaşında kadın hasta acil servise ani başlayan yürüyememe ve şiddetli bacak ağrısı şikayeti ile başvurdu. Hastanın bilinen hipertansiyonu vardı. Distal nabızları zayıf, bacakları soğuk ve soluktu. Alt ekstremitelerinde motor kayıp mevcuttu. Çekilen bilgisayarlı tomografide aortun kökünden başlayan iliak arterlere kadar uzanım gösteren aort diseksiyonu saptandı.

Sonuç: Aort diseksiyonunun nörovaskular semptomlarla başvurusu çok sık değildir. Teşhis ve tedavi tekniklerinde giderek ilerlemeye rağmen halen morbidite ve mortalite oranları yüksektir. Bu nedenle yüksek klinik şüphe ve erken teşhis önemlidir.

Anahtar Kelimeler: Aort diseksiyonu, bacak ağrısı, nörovaskular semptomlar

Geliş Tarihi: 13.02.2013 Kabul Tarihi: 13.05.2013

\section{Introduction}

Acute aortic dissection is a challenging clinical emergency, first described by Morgagni more than 200 years ago. In 1958 , Hirst et al. reviewed 505 patients with the condition, highlighting the high mortality rate and the infrequency of antemortem diagnosis. Still, aortic dissection is the most common acute aortic condition requiring urgent surgical therapy. Separation of the layers within the aortic wall characterizes dissection. Blood enters the intima-media space, with further propagation of the dissection. Typically, 1 or more tears in the intimal layer allow communication between the 2 lumens (1).

Once acute aortic dissection has occurred, symptoms and signs can be produced by rupture or the occlusion of a major vessel. Chest pain is the most common and dramatic symptom. Although most patients experience sudden severe pain at the moment of dissection, the dissection very rarely can be painless (2). Clinical presentations with neurological manifestation or limb ischemia are atypical.

We present an unusual case of a patient who presented with neurologic symptoms of aortic dissection and severe pain due to limb ischemia; paresthesia of the lower extremities and acute bilateral leg pain were the only symptoms. 


\section{Case Report}

A 55-year-old woman was admitted to our emergency department because of a sudden inability to walk and severe leg pain. She had been well until 1 hour before admission, when she noticed the sudden onset of pain, weakness, and numbness of the legs. She had no chest or back pain. Her medical history included hypertension and hyperthyroidism. She was taking antihypertensive drugs. Her vital signs were as follows: blood pressure, 220/100 mm Hg (right arm) and 240/110 mm Hg (left arm); pulse, 92 beats/min and regular; respiration rate, 18 breaths/min; body temperature, $36.3^{\circ} \mathrm{C}$; and oxygen saturation on pulse oximetry, $98 \%$. She was agitated because of severe pain. Her cardiac and respiratory systems evaluations were normal, her distal pulses of the right upper and lower extremities were so weak, and her left femoral pulse was weak. Both of the patient's legs were pale and cold. Examination of the nervous system, including higher mental functions, vision, and the cranial nerves, yielded normal findings. Deep tendon reflexes were absent in the patient's legs, and she had motor deficits in the lower extremities. An electrocardiogram was normal. For hypertension, a beta-blocker (esmolol) and nitroglycerin intravenous infusion was started; for her pain, intravenous morphine $5 \mathrm{mg}$ was given. Routine laboratory tests were sent, and two packages of erythrocyte suspensions were achieved. Because of severe sudden pain and pulse deficits, she was sent for CT angiography with an initial diagnosis of aortic dissection. Computed tomography revealed an aortic dissection from the root of the aorta to the common iliac arteries (Figure 1 and 2). There was no rupture. The true lumen of aorta was so thin along the thoracic aorta, and its width was decreasing to $2.5 \mathrm{~mm}$ in the distal part of the descending thoracic part. She was taken to the cardiovascular intensive care unit. A stent was placed to enlarge the true lumen. Then, endovascular graft implantation was done. But, she died after 1 day.

\section{Discussion}

Acute aortic dissection is the leading cause of death among aortic pathologic conditions. In aortic dissection, the layers of the media are separated by a column of circulating blood, with variable proximal and distal extension throughout the length of the aorta (2).

Presentation of aortic dissection with neurological manifestation is not so common, and the incidence varies from 18\%-29\% in different studies. Weisman and Adams were the first to describe a series of patients with neurologic syndromes as a result of aortic dissection. Neurological abnormalities as a result of aortic dissection can be accounted for by three factors: ischemia of the brain, ischemia of the spinal cord, and ischemia of the peripheral nerves $(3,4,5)$.

Normally, apart from pain, paralysis (inability to wiggle toes or fingers), and anesthesia (loss of light touch over the dorsum of the foot or hand), the symptoms and signs of acute ischemia are nonspecific or inconsistently related to its completeness. Acute limb ischemia is most commonly caused by acute thrombotic occlusion of a preexisting stenotic arterial segment (60\% of cases) or by embolus (30\%). Other causes are trauma, iatrogenic injury, popliteal aneurysm, and aortic dissection. Aortic dissection may cause upper

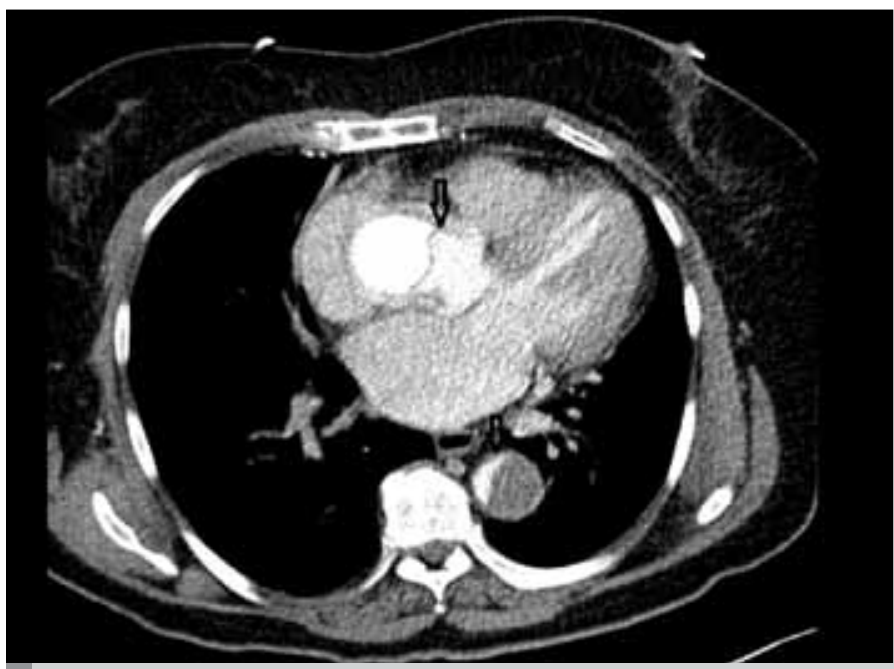

Figure 1. Transverse CT images. Dissection of aorta and nearly total true lumen occlusion

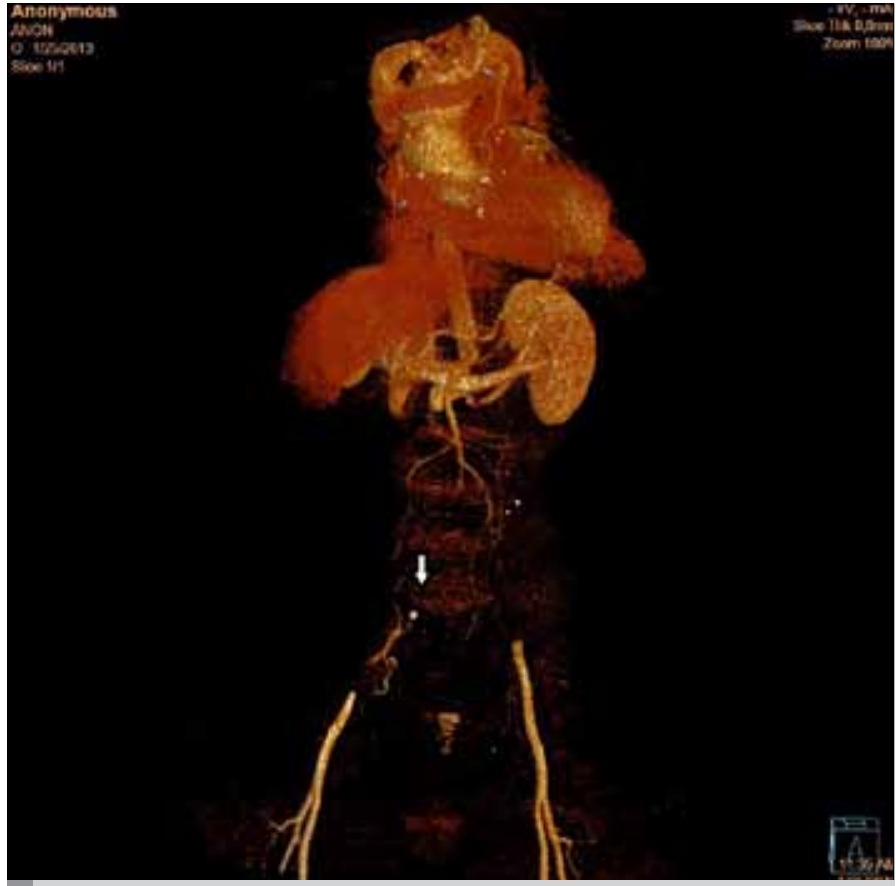

Figure 2. Coronal CT angiography images revealing iliac artery occlusion

and lower limb ischemia due to pinching of the ostia of the relevant arteries by the false lumen (6). The usual differential diagnosis of spontaneous acute leg ischemia includes embolization, thrombosis associated with preexisting atherosclerosis, and iliofemoral thrombosis. Occasionally, an aortic dissection may extend into the iliac, femoral, or superficial femoral arteries and cause leg ischemia. Such an occurrence is typically associated with clinical manifestations of thoracoabdominal aortic dissection $(7,8)$.

Acute aortic dissection may be uncommon, but complications occur often and early, and the outcome is frequently fatal. Since dissection is a dynamic process that may occur anywhere within the aorta, the clin- 
ical spectrum of presentation is broad. Symptoms may mimic more common disorders, such as myocardial ischemia or stroke, and physical findings may be absent or suggestive of a diverse range of other conditions. Therefore, dissection is often difficult to diagnose, and a high clinical index of suspicion is mandatory. It is important to consider the connection between lower extremity symptoms and possible aortic dissection. Despite significant advances in diagnostic and therapeutic techniques, morbidity and mortality rates remain high.

\section{Conclusion}

In our case, we intended to illustrate a category of patients that may be easily overlooked and therefore go untreated by those who are primarily concerned with the patients' neurological or neurosurgical condition. These patients may be seen by a neurologist for an event or a series of events involving ischemia to the brain, spinal cord, or the limbs and their nerve trunks or may be seen by neurosurgeons for disc hernia. So, emergency department patients should routinely be pursued by careful attention to some of the characteristic and simple non-neurological aspects of dissection of the aorta. These should include, in particular, examination of the peripheral pulses and following of vital signs. So, a high clinical index of suspicion is necessary.

Informed consent: Written informed consent was obtained from patients who participated in this case.

Peer review: Externally peer-reviewed.

Author contributions: Concept - S.E.E., Ö.E.O.; Design - S.E.E., S.Ö., Ç.Ö.; Supervision - A.D., H.A.; Materials - H.D., Ç.Ö.; Data Collection and/or Processing - H.D., Ç.Ö.; Analysis and/or Interpretation - A.D., Ö.E.O.; Literature Review - Ö.E.O., H.A.; Writer - S.E.E., S.Ö.; Critical Review - A.D., H.A.

Conflict of interest: No conflict of interest was declared by the authors.
Financial Disclosure: The authors declared that this study has received no financial support.

Hasta Onamı: Yazılı hasta onamı, bu olguya katılan hastadan alınmıştır.

Hakem değerlendirmesi: Dış bağımsız.

Yazar Katkıları: Fikir - S.E.E., Ö.E.O.; Tasarım - S.E.E., S.Ö., Ç.Ö.; Denetleme - A.D., H.A.; Malzemeler - H.D., Ç.Ö.; Veri toplanması ve/veya işlemesi - H.D., Ç.Ö.; Analiz ve/veya yorum - A.D., Ö.E.O.; Literatür taraması - Ö.E.O., H.A.; Yazıyı yazan - S.E.E., S.Ö.; Eleştirel İnceleme A.D., H.A.

Çıkar Çatışması: Yazarlar çıkar çatışması bildirmemişlerdir.

Finansal Destek: Yazarlar bu çalışma için finansal destek almadıklarını beyan etmişlerdir.

\section{References}

1. Hagan PG, Nienaber CA, Isselbacher EM, Bruckman D, Karavite DJ, Russman PL et al. The International Registry of Acute Aortic Dissection (IRAD): new insights into an old disease. JAMA 2000; 283: 897-903. [CrossRef]

2. Colak N, Nazli Y, Alpay MF, Akkaya IO, Cakir O. Painless aortic dissection presenting as paraplegia. Tex Heart Inst J 2012; 39: 273-6.

3. Syed MA, Fiad TM. Transient paraplegia as a presenting feature of aortic dissection in a young man. Emerg Med J 2002; 19: 174-5. [CrossRef]

4. Gerber O, Heyer EJ, Vieux U.Painless dissections of the aorta presenting as acute neurologic syndromes. Stroke 1986; 17: 644-7. [CrossRef]

5. Marcantonio D, Suri P, Coleman K, Taruna A. Aortic dissection presenting as isolated lower leg ischemia. J Emerg Med 2012; 42: 406-8. [CrossRef]

6. Callum K, Bradbury A. ABC of arterial and venous disease: Acute limb ischaemia. BMJ 2000; 320: 764-7. [CrossRef]

7. White TJ 3rd, Pinstein ML, Scott RL, Gold RE. Aortic dissection manifested as leg ischemia. AJR Am J Roentgenol 1980; 135: 353-6. [CrossRef]

8. Huang SM, Du F, Wang CY, Bair MJ, Wang KT. Aortic dissection presenting as isolated lower extremity pain in a young man. Am J Emerg Med 2010; 28: 1061.e1-1061.e3 